\title{
Domination Displaced \\ Gender Norms Imply and Create New Substances
}

\author{
Monique Selim (Corresponding author) \\ 11 Rue de Montyon, 75009 Paris, France \\ Tel: 33-145-231-487 E-mail: monique.selim@ird.fr \\ Anne Querrien \\ 124 avenue du Maine, 75014 Paris, France \\ Tel : 33-143-224-100 E-mail : querrien.anne@wanadoo.fr \\ Mathieu Caulier \\ E-mail : matcaulier@gmail.com
}

\begin{abstract}
Received: January 15, 2014 Accepted: February 14, 2014 Published: February 19, 2014
doi:10.5296/jsss.v1i2.5145 URL: http://dx.doi.org/10.5296/jsss.v1i2.5145
\end{abstract}

\begin{abstract}
This paper analyses the gender global norms, taken in their pluralism, and their different poles and contradictions. It assesses the discards existing nowadays between these norms representations and the plural and diverse local practices. The French, Chinese, Mexican situations are taken as pictures of the general perspective of the authors who question the liberation and also domination logics which interact to create diverse modes of reenacting and recreating these global norms in relation with the social situations of the individual and collective subjects. Gender, feminism and sexualities are the three dimensions of this essay which mixes several disciplines, and several approaches: epistemology, socio-anthropology and politics.
\end{abstract}

Keywords: Norms, Globalization, Market, Care, Men and Women 
The current period, at the dawn of the 21 st Century, is characterised by an intense diffusion of messages concerning membership of categories based on sex and the relationships that should exist between individuals assigned to them. In the light of this overall sexualisation, the world is discovering something that had previously been invisible, buried beneath a universal masculine "neutrality". This sea-change is being presented and legitimised in various ways: the vague notion of "social justice" on which political philosophy placed so much value before 1968 now floats between the poles of morals and ethics with which public policy is summoned to align. Tragic events, emotionally overwhelming, regularly feed the dynamics of the drama in which shades now possess a sex and a "sexual orientation". The little girl raped and forcibly married under Moroccan law to the man who has dishonoured her lineage; the educated woman, after being gang-raped in a city bus in India, who dies of her injuries; the Western journalists raped in public during demonstrations in Egypt; the young homosexuals who are forced to take refuge in a special centre to be protected from intolerant families and associates, and so forth. The unending list of iniquities reminds us that in general throughout the world, in societies both close to and remote from our own, irrespectively of their nationality, women and people whose sexuality does not conform to the dominant model are subjected of perennial violence.

Transmitted through Internet, this ideological universe is now so familiar that it seems self-evident. Its revolutionary emergence is the sign of the modernity and modernisation that all peoples and individuals are called to, no matter how remote they may be from it. The phenomenon can be designated by the polysemic term of gender that comprises a plurality of norms; it is marked less by unity than by inner tensions and heterogeneity, with imports and exports, going through ceaseless redefinition. It is an aggregation of norms. We propose to examine the contradictory processes of normalisation that flow from it, studying successively the superposition of the terms feminism and gender in the context of global and national public policy (in France, Mexico, China); the internal contradictions between equalitarianism and dispositions specifically concerning women; resistance to integration into gender; and last by not least gender norms in the fields of work. The analytical perspectives we will develop here concern the institutionalisation of gender following the crucial contemporary phase that saw the emergence of new feminist movements.

\section{Gender policies on worldwide scale}

Gender, feminisms and public policies spring from a complex history. This is particularly true in the field of international policy. Governments find it difficult to actually put into effect their decisions on gender equality. This is why non-governmental organisations have sprung up to promote gender policy on a worldwide scale. Their efforts have three main thrusts: (1) reproductive health and the battle against infant mortality (natal and peri-natal), and the development of birth control by women; (2) generalisation of wage-employment and personal services, and the development, thanks to micro-credit, of entrepreneurial attitudes in women as a response to precarious economic circumstances; and (3) symbolic policies that on the one hand represent women as victims par excellence of the brutality of the world, and on the other hand promote over-arching, consensual governance. These orientations have been officialised at the UN summit held in 1995 in Beijing, which gave up the former policy of 
promoting equality between men and women, and adopted a new stance. The traditional battle against inequality between men and women was no longer the sole focus; the "sex-specific" difficulties faced by communities of different types were henceforth to receive the same amount of attention. Thus feminist demands were downgraded, and had to share available attention with expert operations on gender.

This worldwide trend can be seen on various continents. We have traced it mainly in the United States and Latin America, which pioneered in promoting governmental feminist policies. The first UN summit on the promotion of women was held in Mexico in 1975. It was through the conquest of positions of power in the major philanthropic foundations that North-American feminists laid the foundations of institutionalisation of feminist political agendas, installing them at the heart of international institutions, and in particular UNO. Gradually consolidated, feminist positions in the Ford, Rockefeller and MacArthur foundations spearheaded reforms in population policies, at the same time as setting up institutional bases from which women - most of whom came from academic backgrounds developed a new field centred on health issues and reproductive rights, together with Latin American partners.

Construction of a global space for gender thus took place within a particular framework: that of the reform of anti-natalist birth control policies in countries of the South (Cairo Conference, 1994). However, it was not so much the "reproductive health" of women that activists from the major United States foundations promoted at the expense of "population"; it was "gender": gender was established as a norm for public policy. "Gender" was to become synonymous with "women", as the Mexican example will show.

\section{Feminism and Gender}

Though gender is involved in all the "sex-specific" concerns advocated by communities dedicated to them, today it is almost always associated with feminism, the terms often being interchanged automatically as though they covered the same thought-space. This hides from view an important difference between on the one hand the social movements that originally contested the established order, including the sexual order, their profiles varying from one country to another, and on the other hand the norms of global governance that had to be taken into account in formulating public policy, whether favourably or unfavourably. Agents claiming new rights or inventing new modes of liberation tend to perpetuate confusion of these two very different things: movements and norms. As a result, governance procedures and normalisation processes weaken the power to imagine freedom. In other words, integration into categories of ascription becomes imperative, gradually banning freedom from ascription, on pain of anomie. A particular "sexual orientation" has either to be chosen or is ordained; on this basis the identity one has selected is subsequently recognized, serving thenceforth as a foundation for claims.

\subsection{Women Communitarianised}

Once this has been done, rights can be accumulated. Behind the identification of feminism with gender (and vice versa), we can discern a series of transformations that are decisive in 
economic, political and ideological terms. If there are such things as "laws of gender"i - to quote a formulation that solidifies from day to day to the point of becoming a biological mime - where else can feminisms take root, whether one interprets the term "law" as something that can be reformed or as an intangible principle. Gender as an eponym equating feminism with sex sends us into a field of governance that belongs to the current globalised world, a world that has been unified by the financial capitalism. Seen from this angle, the construction of governable communities - each a monad with its own specifications - is a necessity. One of the very first changes made is to set up belonging to a sex as the foundation of the community of women, who thus become the first of the "sexual minorities". Before this can be done, however, membership of the female sex has to be established as a negative qualification, so that it can be used as a container of the exclusions and stigmatisations applied to women, all with a view to demanding the appropriate positive remedies. Today the discourse that categorises women as one of the communities suffering from discrimination is so widespread that it seems to be describing a self-evident truth that no reasonable person could possibly deny. We will take just one of the many examples of this - interesting because it shows the link between the negative features mentioned above and employment and career paths. In an interview entitled "Business leaders suffering from disabilities are abnormally effective", the sociologist Norbert Alter ${ }^{\mathrm{ii}}$, who has studied expert atypical business leaders, argues that negative and positive factors are possibly changing places. Resilience has become a popular theme in the current time of crisis, and this is a new version of it, both exorcising and acting as a "pick-me-up" for those unfortunates who have not been blessed with capital. In the Alter interview, the "communities" concerned are listed from the outset: the disabled, the self-educated, people from immigrant communities, homosexuals, and last but not least, women. In this surprising - and disturbing - jumble of profiles defining communities that hold equivalent rights, women are paradoxically disadvantaged; compared with the homogeneous demands of the disabled or the people of such and such an ethnic origin, women's demands are too varied, and this dilutes their voice. Apart from this, there are also women in each of these other communities, and this qualifies them just as much as their biological nature. The logic of this discourse postulates that differences - of origin, sex, sexual orientation, all traits seen as so many disability markers - confer more strength, empathy, and commitment on the individual concerned, obliging her (or him) to stand apart and live up to expectations, performing better and better. Women have been convinced of this from their earliest age; but with the advent of gender they have now also learned to think of their membership of a sex as a genuine disability and a form of ethnic assignment. This makes them different, to go by the French governmental mission on parity and the battle against discrimination (MPADI: mission de la parité et contre les discriminations); in 2010 this body underscored the persistent inequalities that "affect mainly women, the disabled, and French citizens who spring from other cultures".

\subsection{Institutionalisation of Gender in France}

Now enforced by government, whereas historically feminisms come to being in the course of revolts and aspiration to change in social orderings, increasingly gender is becoming an institution, ever more radiant, more visible, an overhang looming over the organisation of 
knowledge and practice. In France, a Ministry of Women's Rights sedulously infuses its preoccupation with gender into all government programmes that compete with its own. Its internet site provides an account of its day-to-day activities, weaving the question of women into the media society, multiplying events recorded in video. The scientific programme of the Gender Institute (Institut du genre), set up in 2013 under the aegis of the CNRS, the umbrella research body, with universities and State research organisations taking part, illustrates this determination; in the preamble, it reminds the reader that "in France today, studies of women, gender, and sexualities, though developing remarkably, are not visible enough". The objective is to promote an interdisciplinary approach to all research themes, "gendering" them methodically irrespectively of their concerns: epistemology, politics, territories, globalisation, production, the market, art, religion, or anything else. Over and above this intention - based on the fact that all social fields, whether material or immaterial, are shot through with sexual relationships - one wonders about the various logics of adhesion that are activated by this ideological mobilisation, which turns out to be a general platform for both public policy and that of the interlocking and overlapping NGOs.

In the new context of de-industrialisation, in France and other mature industrial countries, the main problem is to recover the intellectual and social value of women's work. Freed by social institutions from household tasks and child rearing, women are able to engage in paid employment and entrepreneurial activity. The development of girls' education enable them to take on more significant responsibilities. Though the time-honoured "glass ceiling" remains, maintained by the sheer weight of tradition, it is no longer seen as functional in the new economy and in the development of "care". Reproductive health is ensured by the social security system and the pro-natal policies introduced after the Second World War. The legalisation of contraception and abortion demanded by feminists opened the way to full personal involvement of women in a society based on work and consumption. The current trend is to mobilise the energy of working women, their resistance to adversity and their resourcefulness. The idea of work itself has been affected: work is no longer seen as a mechanical repetition of a few fixed movements on a production chain, or as the supervision of such movements; in situations of uncertainty, it is far more a question of composing, repositioning, and adapting to new developments. The narrative developed in France by the Ministry of Women's Rights is aimed at a mobilisation of this sort, offering prizes and organising events designed to promote imitation. This mobilisation can be seen in particular in aid to abused women and in the struggle against sexual harassment.

The contradictory nature of gender policies can be seen in particular in the development of "care": solicitude for the vulnerable, helping them and looking after them, is apparently seen as a specifically feminine activity (Laugier et al. 2009 ; Toronto 2009 ; Laugier and Molinier 2009), the reason for the massive employment of women in the personal services sector: they form $90 \%$ of the personnel. This noble vision fails to take account of segments in which the majority of the workforce is female: e.g. the cleaning up of business premises, or cash desk operation in supermarkets. Not to speak of nurses, ward assistants, primary school teachers and helpers, and other fields in which headquarter decisions are made mainly by men and carried out in the field mainly by women. In these segments employment is rarely full-time 
and stable, and does not constitute a career. The social rights involved are more limited than those conferred by jobs held in majority by men. Employment norms promoted by gender policies, purportedly adapting them to the constraints with which women are burdened, usually turn out to be unfavourable to females. Thus, whereas the feminist struggle aims at freeing women from this perverse heritage, "care" policy helps to idealise it, enclosing women in an eternal femininity. Part-time, adapted work-hours, and temporary contracts that purportedly make it easier to take care of children and the old-aged merely establish continuity between unpaid domestic labour and unskilled wage -labour.

This is a far cry, however, from the underpinnings that could explain the growing interest in gender issues among academics and association activists in France. In the French case, the source of the mobilisation is not a deficit in democracy; it is rather the perception of persistent sexualised blocking processes affecting the allocation of power in all social, political and economic fields. The ideology of gender achieves a break into representations that are mainly masculine; female agents use it as a weapon to fight their way upwards in the hierarchies. This aspect of gender - its availability as a springboard - brings out the intrinsically normative nature of gender in areas where compromises are needed between family, maternity, employment and career. Gender seems polite and pleasant; it is available to all, respects femininity and maternity, the couple and the family; it is no longer provocative, as it used to be in the mischievous 1970s; today this spirit survives in only a few tiny groups such as La Barbe, that interrupt board meetings and academic conferences to draw attention to the massive predomination of males in the attendance. Stylishly conservative and moderately liberal in France, gender has become an integral part of the "good governance" of the country, spreading its aura by dint of decrees, smiling faces, and sage measures that in actual fact pose hardly any threat to the bastions of masculine power.

\subsection{The dulling of Gender}

Accompanying the development of financial globalised capitalism, gender, in becoming an ideological tool of government, has lost a number of the thrusts that once upon a time had inspired feminist movements, despite their plurality. As Nancy Frazer has found in her rigorous study (Frazer 2012) focused on habitual behaviour, "mores" and the sphere labelled "cultural" in the United States, in deserting the field of economics, social policy and redistribution, gender has contracted a "dangerous alliance" with neo-liberal policies. Becoming an integral part of globalisation, with the intention of making it more equitable and moral, but which it also inevitably stimulates, gender has become a sort of disconnected injunction, similar to those used by Communist governments during their planning periods. Public and private research thus produces an incessant supply of mechanically gendered knowledge in response to increasingly numerous calls for more and more specific approaches that tend to efface more general issues. Feminism and gender thus turn out not to be interchangeable after all, and though at certain points bridges can be found between the two topics, it is nonetheless preferable to keep them distinct. This is why expressions such as "State feminism" and "feminist State" apparently give rise to more misunderstanding than understanding of the configurations involved ${ }^{\text {iii }}$. State feminism has been identified in cases as different as Mao's China and Sarkozy's France. In China, public policies promoted women's 
activity outside the household, abolishing a number of customs that were obstacles to women's work (foot-binding, arranged and prescribed marriages, etc.). Employment of women was modelled on that in the USSR, which at the time was providing economic aid to China, in accordance with the Party-State doctrine. The French government during the Sarkozy presidency (2007-2012), on the other hand, used the emerging women's movement women's freedom, equality - in its construction of a national identity aimed at forcing out foreigners, sending them back into a putative "barbarity". The financial crisis was leading to mounting unemployment and the call for "giving preference to nationals" was percolating into the political sphere. This was no more feminism than Bush's crusade in Afghanistan intended purportedly to free women from the horrors of male domination.

We note, however, that throughout the world men and women are frequently duped by these governmental campaigns promoting women's rights. Their trick is to present a praiseworthy intention, while masking the economic interests and political manoeuvres that are behind it. Proclamations can seem all the more striking when detached from the economic levers that have produced them, their decorative function alone being left on show.

\subsection{NGO Gender}

Strongly promoted by the international conferences of the International Women's Decade in Mexico, Copenhagen and Nairobi, gender norms became global during the 1980s and 1990s. In 1979 the United Nations and the signatories of the CEDAW ${ }^{\text {iv }}$ intended to guarantee these norms, despite the fact that they had not been properly integrated into national legislations. Rio, where $\mathrm{WEDO}^{\mathrm{v}}$ was very active, and Cairo, marked a turning point in the incorporation of norms of gender equity into conferences on the environmental and on population, making gender norms an essential axiological component of the democratic governance promoted by international organisations. The conversion of gender norms into universal values also owes a lot to the institutionalisation of feminist studies in American universities, where they are known as Women's Studies and Gender Studies. Today, throughout practically the whole world, with few exceptions, gender studies have become an academic and scientific norm, reflecting changes in North American academia (El Maleh, 2003; Guilhot, 2004: 36-48; Bourdieu \& Wacquant 1998: 109-118). Bolstered by these field effects, global gender norms have been set up at the heart of the UN system; they were eventually canonised at the last major international conference on women, which was held in Beijing in 1995, under the aegis of the UN. Ever since the two leaders of the IWHC (International Women's Health Coalition) managed to forge alliances with women heading other foundations, methodically putting pressure on central agents in the field of population policy so as to have their male or female friends lead humanitarian programmes (Carmen Barroso), NGOs - and in particular their main funding sponsor, the Ford Foundation - have opened up to the new health standards promoted by charitable foundations in the 1990s. The consensus reached in Cairo enabled the organisations controlling population policy to avoid repeated attacks by feminists and made these organisations part, in their own right, of the UN normative system as organisation dedicated to the reproductive health of women. Slowly but surely this process of conversion spread to all organisations involved in Population Control. Some of these underwent radical conversion, basing their image and communication on gender. 
In many cases women who use humanitarian foundations to further their own feminist agenda also take part in the ideological struggle against religious conservatives and the Republican Party; as a result struggles specific to the American political and academic fields are brought into the more general feminist discourse, and can to a large extent be seen as American "exports". In a Latin America led - paradoxically - by Chicago Boys, North American women with influential positions in humanitarian foundations found objective allies in feminist and academic debates. Humanitarian funding thus tended to mimic and reproduce in the South the women's struggles of the North. In the process the modes of action of feminist movements underwent considerable transformation, giving rise to differentiation within South American feminist movements. The latter soon became professional, involving themselves in the preparation of UN conferences that had previously aroused little interest in feminist circles. In the process of making the new norms an integral part of international policies, agents promoting the reform of population policies were to find allies in many of the national social spaces; thus, with the support of US philanthropy, this process led to the development of a genuinely transnational social space. The latter in turn gradually grew local roots, bringing in new gender-entrepreneurs and gender policies. Fusion was made possible by the international funding previously allocated to population policy and subsequently, in the early 1990s, redirected to "reproductive health".

\section{The Two Poles Of Gender Policy}

As we have already explained, "gender" is a mosaic of norms that is constantly evolving. These norms appear to stretch between two poles; the tensions find their way into all gendered programmes. Over and above the various connotations of terms such as equality, parity, or sharing, all of them pull gender towards one of the poles. Care, on the other hand, and all the specifications and qualifications linked to membership of a sex, bring out the eternal feminine, ranging from solicitude to empathy, from proper management to gentleness and efficacy, in short, to all the stereotypes that glimmer anew in microcredit, in women's self-employment and in their empowerment. The symbolical efficacy of gender draws much of it strength from this sustained vagueness, this dogmatic avoidance that enables each one of us to seize the ideological filament that suits him or her, twisting it in his or her own manner. This is all the more effective as no matter what side they are on, egalitarian, paritaire or independent - as mistresses of their own arrangements - women remain basically "communitarian" - like all the other categories they are often assimilated and sometimes opposed to (Muslims in favour of the headscarf, Africans practicing excision, and so forth). The communitarian interpretation that assigns categories and identities evacuates de facto the political framing of the production of social relationships concerning sex and the importance of the form of State (democratic, authoritarian...) in women's adhesion to the gender modules. The inter-sectional tripartite division according to Sex/Race/Class has been revived in France in all its monotonous variety as a way of denouncing "white epistemology", and the hegemonic, imperial feminism deriving from "black queer" and the underlying American political configuration centred on so-called "racial" communities. These terms are applied "raw", so to speak, obscuring the history and the political situations they were intended to clarify. To understand the seductiveness of this ideological apparatus, one has first to drop the 
vision based on identity and return to the social, economic and political relationships that underlie the production (in the theatrical sense) and staging of a particular "community". Undertakings of this sort are very difficult indeed when one refuses to target the agents involved as part of a "community" in the manner that has become habitual today, with their affects re-naturalised. If, on the other hand, one recomposes the entire picture of which the agents are really part - and if one analyses in particular the process of relegation that has led them to identify with such and such a paradigm, the explanation is a good deal simpler. Unfortunately, it is becoming increasingly difficult to avoid binding agents with the bonds they have forged for themselves in the ideological realm of gender. The tripartite division according to Sex/Race/Class, assumed unquestioningly as a basis of identification, legitimises de facto antagonisms on this basis, as critics are currently noting more and more (Palomarse and Testenoire 2010).

\subsection{The Chinese Example}

The political framework and the form of the State weigh heavily on mobilisations of educated women in and around gender training modules. China provides a conclusive example of the contradictory processes that come into play. The central economic role of China in globalised capitalism no the one hand, and on the other the nature of the Chinese Party-State that maintains a monopoly of power, combine to disrupt the idea of global governance as a system anchored in the generalisation of democracy. Democratic rights are becoming more and more formal and less and less social and economic. Though the Cold War ended with the fall of the USSR and the conversion of the last communist countries (Vietnam, Laos, and beginnings in North Korea), the financial arrangements of international organisations show clearly that the latter are determined more than ever to continue their campaign for the rights implicit in format democracy. Seen from this point of view, women are crucial to the campaign, women's rights spearheading the advance in democratisation at the expense of the Party-State. By importing to China gender studies and LGBT, by aiding the establishment and management of NGOs, and by organising public performances presented as avant-garde demonstrations, policies tested in post-Communist Eastern Europe are being applied on an ever-increasing scale. In Romania in particular, following the collapse of the Party-State, learning to run democracy was put on the university syllabus, and female academics were energetically mobilised to act as avant-gardes (Cirstocea, 2006). In China, however, the construction of a civil society in which women play a decisive part, and the incorporation of democratic spirit are preceding the hypothetical collapse of the Party-State.

Educated women, the initial targets of external intervention, are all the more sensitive to these issues as they are subject to a range of dominations that coagulate in work, the family and kinship. Political hegemony, with power vested in male representatives established in various public and private eminences that interlock and over-legitimate one another, makes rebellion, whether individual or collective, a very risky undertaking. The expansion of market economy and of consumerism has promoted new hierarchies, turning women - and also men - into mere commodities, and hardening social relationships between the sexes. The harshness of male domination is felt e.g. in women's de facto obligation to marry before the age of 30 and to produce a male descendant if they are to avoid being relegated to the cupboard of 
"left-overs". Rare are the women who manage to resist this normative coercion. The reason for this is perhaps habituation to political norms that provide models for norms of personal behaviour. As a corollary, new behavioural models brought in by globalisation appear to women as calls for liberation; desires long buried and continually repressed emerge suddenly in dazzling splendour. Thus democracy slips in under cover of gender. The same can be said of the right to a non-polluted environment, the right to healthy food, and the desire to preserve old neighbourhoods as vestiges of history. Themes of this sort overlap and intersect, constituting the emerging civil society (Selim, 2013). The latter can also be detected in the homosexual groups burgeoning thanks to digital communication (Guo, 2011).

\subsection{Mexican Developments}

In Mexico, where the complex national context is closely linked to that in the United States, the use of gender as a scientific category was problematic because in Latin America it was difficult to translate the term satisfactorily (Corrêa et al., 2003; Lamas, 2006; Bartra, 2005). During the past two decades estudios de género have more or less taken over and replaced in Mexico, as in the rest of Latin America, estudios de la mujer (Bartra, 1999; Bonder, 1998). This methodological and conceptual transformation owes a lot to the closeness of the United States, and also to the close involvement of Mexican feminist anthropologists in the preparation of the international conferences held in Cairo (1994, on Population) and in Beijing (1995, on Women), which canonised international use of the concept of gender in public policy and activism (Caulier, 2009a; Eager, 2004). All the work involved in integrating gender into political processes and institutionalising it has been led by a conjunction of North American interests (Caulier, 2009b). The latter are positioned between the academic sphere and the humanitarian foundations on the one hand, and on the other Latin American feminists who had already been involved in the first phase of institutionalisation, active in the social movements of the 1980s for the democratisation of the continent (Caulier, 2010). This conception of gender was to become the norm in Mexican politics. Today it conditions the intervention of ministries involved in educational, healthcare and family policy. Inflated discourse on "policies with perspectives in gender", as the phrase goes in Mexico, often masks non-democratic practices incompatible with their liberal North American political model. Public display of "gender" cannot hide the bellicose spiralling that has marked recent years. The political and economic situation of women, despite the fact that they are receiving so much benign governmental attention, had never been under so much threat as it has during the recent years of crisis in the civil war against the cartels. To the official figure of 70000 killed should be added the untold number women raped and murdered in a climate of virtually total impunity, victims of violence in the sphere of work. These facts annul to a large extent the good intentions of two decades of "gender" policy focused - far too closely - on reproductive health of women and their sexual rights. The real advances (de-penalisation of abortion in Mexico and civil union of persons of the same sex) gained by feminist movements and institutionalised in NGOs and academic gender studies cannot hide the narrow, specialist nature of these studies, focused on obtaining sexual rights in accordance with the US model - thanks to funding from humanitarian foundations - and the loss, in the process, of political and social rights for both men and women. Facing economic crisis, the 
political and institutional edifice supporting gender policies fissured and cracked; born in a unique historical moment - the end of the Cold War and the definition of democratic norms for the societies of the South - these flaws were inherent in the construction of the institution.

With a synchronicity reminiscent of that in the former Communist countries, Mexico underwent a forced march towards democracy in order to keep in step with the new political formats promoted by the United States in the early 1990s. Practical outcomes were multiple, with "gender" being used as a variable in the central assumptions committing the State to democratic "values" and forms. One often gets the impression of an almost theatrical interplay smoke and mirrors, with the Mexican political elites willingly playing the "gender" game (or alternatively those of "homosexuals" or "indigenous peoples") for the benefit of the great Northern neighbour. In an unending telenovela, the real political forms of Mexican institutions are veiled from the eyes of the world, though clear to Mexican citizens. In a political system that only seems to be democratic, playing the "gender game" merely helps to dissolve the real social relationships of sex, class and ethnicity in a make-believe democracy involving local Mexican institutions, North American sponsors and local NGOs, and masking the incredible violence of a society in which rape, the murder of women and the lives they are forced to live in these times of crisis are all blithely ignored by the government and provincial authorities. As of 1995, for example, during the first phase of legislators' and activists' progress, gender was highlighted in public policy; meanwhile, the increasing militarisation of the State and the almost total deregulation of labour helped to drain of all substance the material manifestations of action in favour of women, which has subsequently dwindled into the sporadic assistance we can witness today. Budgets for which the feminists had fought hard (reproductive health, birth-control, etc.) have been cut drastically; as a counterpart the Government has passed laws that turn out to be virtually inapplicable (the General Law on Life without Violence for Women) while, together with the military, it is directly involved in the violence that is affecting women.

\section{Resistance As Part of Gender Normalisation}

Gender norms are plural, as we have already mentioned; they are stretched between opposing poles. The practical and ideological field of gender expands constantly to limits that in the eyes of agents constitute at any given moment impassable frontiers, so tense do the contradictions become, giving rise to disorder and undermining the consensus on which gender arrangements rest. Yet, rather than concentrate on these apparently irremediable disagreements, it would probably be more useful to look at moments of extreme tension as indicators of possible future advances that promise to bring together the intellectual and the existential aspects of the gender problem. As things stand today, we see two major thrusts dramatizing conflicts and passions and justifying reciprocal anathemas. The first of these presses singularities beyond the bounds set by universalistic opinion. The second pushes the market to the point at which it contravenes the precepts of basic "morality".

\subsection{The Postcolonial Singular Perspective}

In an historical category we call "singular", we class Islamic feminisms (Ali, 2012) and women's groups - e.g. the "white" feminist collective for equality (Ewanjé-Epée and 
Magliani-Belkacem 2012) - that motivate struggles by labelling them "postcolonial". Here, arguments confront counter-arguments in a standoff. On one hand people denounce the perpetuation of deeply rooted historical dominations that fuel racism and oblige women to deny the groups to which they belong by tradition, together with their rules and customs. The expression "loyalty conflict" sums up what is at stake: emancipation comes into conflict with existing connections. Certain signs are attacked, seen as manifestations of women's subjugation and as behaviour that precludes the proprieties of gender and the etiquette of the feminist "establishment". Using adjectives (e.g. white/black) that bring back "race" or restore political situations that are now outdated (e.g. coloniser/colonised), activists engage in trench warfare between opposing camps: ritual conflict that occupies publications and encounters of every sort. Reproducing in a spectacular way the relationships of domination and exclusion that characterise French society by reviving the stigmata that they inflict, these diatribes are in fact first and foremost vectors of symbolical insertion into the ideological space of gender. The numerous currents in "Islamic feminism" all designate advance in the recognition of women's rights in the terms prescribed by gender norms; the opposite poles (equality and women's specificity) are reconciled metaphorically in a new "community" that is trying to place itself in an enlarged orbit. Could this be the avant-garde of a globalised governance of gender that will show up as reactionary or at least conservative all people who deny to others the right to think of themselves as feminists and declare themselves as such? The Kuwaiti feminist Mai Al Nakaib is an example; she proposes to use Deleuze's sophisticated concept of disjunctive synthesis (i.e. grasping two different things in a common field of differences) as an articulation between Islamic identity feminism and the feminism of rights (Hawkesworth 2012).

\subsection{The Market And Its Sexual Avatars}

The second thrust transforming the limits and norms of gender is that involving the market and its sexual avatars: the commercialisation (sale or rental) of one's body, entire or in part, for recreation or procreation. The issue centres on prostitution and on remunerated childbearing on behalf of third parties, in particular male homosexual couples who opt to take part in the current normalisation process. Here, counter-arguments tend to revolve around "re-naturalisation" - i.e. the symbolical structure of sexes and their inalienable functions - in tones of metaphysical despair. It is within the space of gender norms that arguments and counter-arguments have been fossilised. On the one hand homosexuals and their various practices must be recognised as one or another of the many "communities" holding rights, including that to indulge in games of domination. On the other hand, however, a sacred ban prohibits putting procreation on the market, i.e. by leasing e.g. a uterus and a few gametes selected by the leaseholder's in accordance his (or her) preferences and monetary resources. As far as pleasure is concerned, men and women should be entitled to market a range of sexual services, priced to suit various types of clientele. But these practices must remain proscribed when in fact they are pioneering the emancipating potentialities of capitalism and its financial instruments...

Gender norms have accompanied the globalisation of capitalism; this stands out with special clarity in the conflicts that in a few decades have come to be seen as outdated and retrograde. 
In all the arenas in which these issues are being debated, the Gift is continually brought in as to free us from the Market. Some participants imagine gestational surrogacy that is "solidarity-based and free of charge"vi , modelled on the gift of oneself, as in maternity or the act of sexual love, and so forth. Sexual aid provided to the disabled by specially trained social workers is a step in this direction, and is gaining ground in countries that follow the lead of the United States (Hamet and Rainfroy 2013), which has pioneered in this (as in the requisite financial arrangements); China is a case in point. Seen from this point of view, sex is simply an aspect of healthcare, a service to which everybody should be entitled. The service does not imply a sexual exchange of any sort, however; there are no questions concerning the provider of the service, whose potential "pleasure", for example, is never mentioned (nor, for that matter, is that of the disabled receiver). Sex, here, is no longer a quest for shared pleasure, but simply a biological need that ensures bodily health. The orgasm is seen essentially as masturbatory, a mere matter of technique - at least in the theory.

\subsection{Gender and Desexualisation}

It could be said that gender as a norm of governance has de-sexualised sex, transforming it into a mere legal right to sex. This right presupposes, however, that its holder "belongs to" a definite sex: hetero-, homo-, trans-, etc. This is why, once one sees a "belonging" of this kind as a substantial trait, one inevitably hesitates: is it by choice or by ascription? As the process of de-sexualisation has several sides to it, each of these leads on to further debates; in recent years these have multiplied. The exasperation caused by the Ukrainian group Femen (Ackerman \& Femen, 2013), for example, is particularly revelatory in this respect, showing how irreconcilable perceptions of sexuality can be in the eyes of the variegated groups claiming to be "feminist". The Femen have adopted a mode of challenge inspired by the activism of the 1960s and its intentions that were revolutionary in the sense established by Marx, Engels, Lenin and Bebel (Bebel, 1891), whose word the Femen have taken as their bible. This can easily be understood in the context of nostalgia for the Soviet era wrought by economic reforms in the former USSR and the reintroduction of the market. Coming from déclassé, pauperised and de-urbanised families, with their country becoming a major destination for sexual tourism and commercial surrogacy, these girls smoulder in a revolt that is political in the fullest sense of the term: it is both anti-capitalist and nationalist. They organise actions in the form of the performances that are taking place throughout the world today, from Europe to China ${ }^{\text {vii }}$. The technique used is that of inversion, transforming breasts, women's sexual attributes par excellence, by defying the conventional rule of decency, from an erotic into a political symbol, undermining the political, social, economic and symbolical foundations of patriarchy.

Taking enormous risks, undergoing frequent and brutal arrests, the Femen put on show the nude bodies that are their main weapon. Their combat, however, is totally de-sexualised, abstracted from the women themselves. Seen in this perspective, the performance is a manifestation of the new "thingness" that reduces sexuality to a service (or alternatively a gift, a right, healthy exercise, etc.). The feminism of the Femen is radical, "sextremist"; it builds, in the Femen's own words, an ideology aimed at liberating the women of the entire planet, renewing internationalist vision whose prophet, Lenin they wholeheartedly admire. The 
political convictions of these young Ukrainian women distinguish them, together with others, from those feminist circles that are currently configured for action only in the field of "mores" and for calls for legislative reform. It is why attacks on the Femen e.g. by Mona Chollet (Chollet, 2013), who refuses to admit them to the feminist microcosm, accusing them of consenting to alienation by using time-honoured feminine seduction strategies, as in advertising imagery, seem now to be outdated and dogmatic, clumsily out of step with the new forms of struggle born with the processes of globalisation. These processes are speeding up: posing nude on the web in Muslim countries now functions almost as an example to be followed. Like their sisters in the Arab countries, the Femen are in fact de-sexualising sexual ascriptions: action at the heart of current processes that are spectacularly dramatising contestation and political claims. Nudity in this context is anti-sexual because out of seduction, the very opposite of what it was in the 1970s, when the fact of stripping was a way of unveiling the eroticism that informs all inter-personal relationships; the Femen have de-sexualised these relationships.

The tenacity of the Ukrainian Femen in their struggle against the various forms of imposed modesty mirrors that of the Islamic feminists who contest the imposition of the veil. Women "put on" a spectacle by "taking off" their tops to show that they exist, what they reject, and what they aspire to. What we observe here, over and above the apparent provocativeness and the polemical intent, is actually an advance of gender: a separate part of sexuality that on the one hand the women relegate to the attic of history, while at the same time using it to define a new identity. Identity is the pivot of every community; it has an architectonic function, providing a foundation for political correctness. To quit the identity that has been ascribed to one - with or without one's consent - it traditionally seen as an intolerable transgression. Judith Butler, in attempting to detach herself from identity and identification and to de-essentialise herself as a subject, exposes herself in the eyes of both Jews and women to the usual accusations of betrayal of both gender and "Jewishness", impelled by "self-hatred" (Butler, 2012). Sex and community are seen as substances, each with its own "essence"; fidelity to them cannot tolerate "confusion in the matter of gender". Correct gender should avoid political adventures, brutal standoffs with governments; it should remain clear-cut out of respect for the "good governance" of the Globe.

\section{Between Work and Gender: Disjunction and Conjunction of Norms of Governance}

From one end of the wide world to the other, under the aegis of gender, inequalities in work are being ceaselessly denounced. Women are being shown as victims of discriminations that are being exacerbated by the crisis; unable to further their careers, they are harassed, poorly paid, confined to subordinate positions, submitted to disjointed work hours, to mention only some of their disabilities. To these ills are added that of being torn between work and family duties, despite some recent improvement in men's willingness to share household chores. This latter claim is not really being stressed much in women's demands, which are still centred on women's ability to give birth and to raise children, and to their duty to nurture and rear the young. At the same time, thanks to a recent adaptation, men are being led to take a larger share in these functions, thanks to the introduction of parent's leave, which now men too can take when a new child is born. In this particular field, homosexual families have now 
become part of the genus "family". Work itself, however, has not yet become a front in its own right in the struggle - as this is not yet urgent; as though the fall in its cost, and its increasing flexibility as it becomes increasingly insecure, were an inexorable part of the economic evolution of societies. The more the disadvantages of women at work become clear at all levels of specific hierarchies, the more measures are identified that should be taken to bring about more equity, but the less, in fact (with certain exceptions ${ }^{\text {viii }}$ ) the fields of work themselves are apprehended in their overall modes of organisation and management as penalising everybody, men as well as women. Thus it is the adaptation of the condition of working women to improve balance between (unpaid) work at home and (paid) work outside it that forms the "plateau" for gender in this field. With no social, economic and political transformation on the horizon, the current form of capitalism, i.e. the financial form, is treated as an intangible datum, as are the "natural" duties incumbent on women mirrored in it. Depoliticised and so to speak de-economicised on one hand, but "communitarised" and "culturalised" on the other, gender becomes a matter of substance and of ethics, suspended above social relationships, but endowed nonetheless with decisive ideological and symbolical efficacy. Thanks to the "harmonising" work/family chimera, gender presides over global governance and guarantees it; meanwhile it lends an incontestable moral tone to everything everywhere - well beyond the contradictory interpretations by people who vie with one another on the internet to impose their particular vision. This is less surprising than it may seem at first; the intention of moral discourse has always been to arrive at a satisfactory arrangement of male-female relationships that can be attributed to some decree, divine or socio-political. Henceforth gender, incarnating all thinkable ideals of justice, no longer has to give an account of itself; throughout the world it features in varied and opposing narratives, nourished by all parties concerned, and at no risk whatever, even to the reigning finance capitalism, that it even flowers with a few symbols of virtue. Its worldwide diffusion becomes a godsend that has to be carefully preserved. Indeed, as sexual communities replace social classes, and at the same time create the illusion, even in the community of women that the latter is being divided against itself by the emergence of competition in women's own proper sphere, that of "care", invoking origins and positions. Indeed, innumerable articles now take to task the "white" women who employ other women, designated as "black", to look after their little ones, and remind them of their neglected duties. Women in managerial positions who employ and exploit female migrants, are seen as "unnatural" and somehow monstrous. They should be ashamed, we are repeatedly told, of their immoral conduct, taking another woman away from the care of her own children to look after those of someone else. And the migrant woman is in turn seen as little more than her own maternal function, "love", without the slightest suggestion that she may have fled from her family precisely in order to go out and discover the wider world. Every woman should simply go home and stay in her original community, enjoying the proverbial warmth of her hearth, cradled in the affection of her nearest and dearest. Little thought is given to women's migrations to work, in rural France for example (Selim 1980), in the early $20^{\text {th }}$ century, or the current migrations from almost everywhere in the world along various routes, old and new. Yet all of these are at least in part liberations, so many quests for imagined freedom.

\section{Dominations: Deviation, Conservation, Circumvention?}


This how the idea of domination has been displaced to other, more specific fronts, internal, more intimate, and thus better adapted to the categories (e.g. black/white) of so-called "post colonial" identity. At the same time, as Christine Delphy has emphasised in her critique of "post-modern feminism", the desire to dominate is not presented as a construction but as a "natural feeling" (Delphy, 2012). Thus, domination can even be something desirable, e.g. in the field of sado-masochistic gratification, with performances taking place in empty spaces bearing no relation whatever to any structure, institution or social relationship; the transgressions involved cannot affect society and its forms. Only power and hierarchies remain, conserving only domination, which is now thought of as ontological.

These conservative displacements of domination leave the economic organisation of the world untouched, to reign over all spaces and peoples, irrespective of origins, taking account in its criteria exclusively of economic resources. Financial identities thus currently constitute the basis of a reality that gender embraces and merely deviates. As Isabelle Guérin shows very pertinently, micro-finance, a financial instrument, targets in priority women, making gender one of its main criteria (Guerin et al., 2009), with a view to exploiting women's skill in putting to fruitful use small sums of money (Garcia, 2010). These objectives, however, have patently not been reached; but microfinance has nonetheless encouraged a vision of the poor as constituting a new and highly profitable market that is recording constant growth. Meanwhile, on another level, gender has turned its back on financial identity and concentrated on archaic mirages of identity, in which it gets bogged down - taking with it crowds of women and men who are groping for a meaning to their lives.

De-gendering feminisms, undoing gender to generate new, pluralised feminisms, gaining a firm grasp of the articulations of globalised dominations, unmasking subterfuges, totalising anew uprisings and revolts: could this be the way, today, in our world of mingling multitudes, to rediscover the transverse paths to freedom in a space without frontiers, without obligatory identities, and without mandatory communities and destinies?

\section{Conclusions}

The article demonstrates that gender corresponds to a polysemic term and a plurality of norms which became global from the 1990s; The conversion of gender norms into universal values owes a lot to the institutionalization of feminist studies in American universities (cf. Women's studies and Gender studies). NGOs recrutes scholars in this curricula and promote gender policy on a worldwide scale. The article analyses how feminism and gender are not intercheangeable. Behind the identification of feminism with gender, a series of decisive transformations in economic, political and ideological terms appear. The gender is used as a variable in the central assumptions committing the State to democratic values and norms. It is a norm of governance but the communitarian interpretation of gender which assigns categories and identities evacuates the political framing of the production of social relationships concerning sex and the importance of the form of State in women's adhesion to the gender modules. 


\section{References}

Ackerman, G., \& Femen. (2013). Femen. Paris : Calmann-Levy.

Ali, Z. (2012). Feminismes islamiques. Paris: la Fabrique.

Bartra, E. (1999). El movimiento feminista en México y su vínculo con la academia. La Ventana, 10, 215-235.

Bartra, E. (2005). Neofeminismo en Mexico. Working Paper from the author.

Bebel, A. (1891). La femme et le socialisme. Paris: Editions Georges Carré.

Bonder, G. (1998). Estudios de la Mujer en America Latina. Washington: OEA.

Bourdieu, P., \& Wacquant, L. (1998). Sur les ruses de la raison impérialiste. Actes de la recherche en sciences socials, 121-122, 109-118. http://dx.doi.org/10.3406/arss.1998.3250

Butler, J. (2012). Parting Ways: Jewishness and the Critique of Zionism. New York: Colombia University Press.

Caulier, M. (2009a). Dall'internazionalismo marxista al neoliberismo globale: i femminismi messicani tra attivismo continentale e impegno transnazionale, 1970-2000. Rivista Genesi,s $7(2), 85-108$.

Caulier, M. (2009b). Le genre des Mexicain-e-s. Revue Tiers-Monde, 200, 805-820. http://dx.doi.org/10.3917/rtm.200.0805

Caulier, M. (2010). The Population Revolution: from Population Policies to Reproductive Health and Women's Rights Politics. International Review of Sociology, 10(2), 321-346.

Chollet, M. (2013). Femen partout, féminisme nulle part. Le monde diplomatique, March 12. Retrieved from http://www.monde-diplomatique.fr/carnet/2013-03-12-Femen.

Cirstocea, I. (2006). Faire et vivre le postcommunisme. Les femmes roumaines face à la transition. Brussels: University of Brussels.

Corrêa, S., McIntyre, P., Rodriguez, C., Paiva, A., \& Marks, C. (2003). The Population and Reproductive programme in Brazil, 1990-2002 Lessons Learned. Chicago: The MacArthur Foundation.

Delphy, Ch. (2012). Genre et race : des systèmes sociaux comparables. Paper presented at Congrès international de recherches féministes francophones, Lausanne, August 29.

El, M., Eliane. (2003). Les politiques identitaires dans les universités américaines. L'Homme et la société 149(juillet-septembre), 57-74.

Ewanjé, E., Félix, B., \& Stella, M. B. (2012). Les féministes blanches et l'empire. Paris: la Fabrique.

Françoise Héritier et les lois du genre. (2013). Produced by Anne-France Sion. Paris: CNRS. Frazer, N. (2012). Le féminisme en mouvement. Paris: La Découverte. 
Garcia, M. (2010). La femme est-elle un homme économique comme les autres? Multitudes n, 42, 94-99.

Guerin, I., Palier, J., \& Benoit, P. (2009). Femmes et micro-finance, Espoirs et désillusions de l'expérience indienne. Paris: Archives contemporaines Editions.

Guilhot, N. (2004). Une vocation philanthropique. George Soros, les sciences sociales et la régulation du marché mondial. Actes de la recherche en sciences socials, 151-152, 36-48.

Guo,W. (2011). Internet: un outil de légitimation pour les homosexuels cantonais. In Enjeux épistémologiques et idéologiques de la globalisation pour les sciences sociale. In B. Castelli, \& B. Hours, (pp.185-212). Paris: l'Harmattan. http://dx.doi.org/10.1109/MIC.2011.50

Hamet, C., and Claire, R. (2013). Handicap: l'assistance à la sexualité en débat”. Le Monde, March $13 . \quad$ Retrieved from http://www.lemonde.fr/societe/article/2013/03/12/handicap-l-assistance-a-la-sexualite-en-deb at_1846682_3224.html

Hawkesworth, M. (2012). Signs - Journal of Women in Culture and Society, 38(2).

L'Humanité. (2013). Debate between Axel Kahn, Sabine Salmon, and Irène Théry, 2, 3.

Lamas, M. (2006). Feminismo: transmisiones y retransmiones. México: Taurus.

Laugier, S., \& Pascale, M. (2009). Politiques du Care. Multitudes, no. 37-38. http://dx.doi.org/10.3917/mult.037.0074

Laugier, S., Molinier, P., \& Patricia, P. (2009). Qu'est-ce que le care? Souci des autres, sensibilité, responsabilité. Paris: Petite bibliothèque Payot.

Le Monde. (2012). Column Eco et enterprise. November 13.

Palomarse, E., \& Armelle, T. (2010). Prismes féministes: qu'est ce que l'intersectionnalité? L'homme et la société, no. 176-177.

Revillard, A. (2006). Féminisme d'Etat: constructions de l'objet, Projet MELISSA. Retrieved from http://www.melissa.ens-cachan.fr/IMG/pdf/feminisme_dEtat.pdf.

Selim, M. (1980). Quelques aspects de l'émigration féminine basque à Paris. Ethnologie française, 5(2), 197-200.

Selim, M. (2013). Hommes et femmes dans la production de la société civile à Canton, L'harmattan.

Tronto, J. (2009). Un monde vulnerable: Pour une politique du Care. Paris: Editions La Découverte.

United Nations General Assembly. (1979). Convention on the Elimination of all Forms of Discriminations against Women. New York: United Nations.

Women's Rights Politics. International Review of Sociology, 10(2), 321-346. 


\section{Macrothink}

Journal of Social Science Studies

ISSN 2329-9150

2014, Vol. 1, No. 2

\section{Copyright Disclaimer}

Copyright reserved by the author(s).

This article is an open-access article distributed under the terms and conditions of the Creative Commons Attribution license (http://creativecommons.org/licenses/by/3.0/).

\footnotetext{
i Françoise Héritier et les lois du genre, film produced by Anne-France Sion, CNRS 2013.

ii Column "Eco et enterprise", Le Monde, November 13, 2012.

iii The notion of State feminism emerges with the advent during the 1990s of the so-called gender policies in favour of women. Gender forms their matrix of reference, as Anne Revillard has shown (2006) in "Féminisme d'Etat: constructions le l'objet", Projet MELISSA, http://www.melissa.ens-cachan.fr/IMG/pdf/feminisme_dEtat.pdf

iv Convention on the Elimination of all Forms of Discriminations against Women, written in 1979.

${ }^{v}$ Women's Environment and Development Organization.

${ }^{\text {vi }}$ Debate between Axel Kahn, Sabine Salmon, and Irène Théry, L'Humanité, March 1' ${ }^{\text {st }}$ 2, 3, 2013.

${ }^{\text {vii }}$ As in China they demonstrated to demand more public toilets, squatting to urinate in front of the City Hall. In Canton women chose to mime the act of urinating by sitting on plastic toilets made with the help of students at the school of Fine Arts.

viii Such as Danièle Linhart, who writes and speaks regularly in the media on mutations and suffering in work.
} 